\title{
Povijest Zbornika EFZG
}

Zbornik Ekonomskog fakulteta u Zagrebu je međunarodno prepoznat i renomiran časopis koji već dugi niz godina objavljuje znanstvene i stručne radove iz područja ekonomije i poslovne ekonomije. Na taj način doprinosi važnoj i vodećoj ulozi Ekonomskog fakulteta u Zagrebu u širenju znanja i promicanju ekonomske znanosti na području Hrvatske i zemalja u regiji. To je ujedno i najmlađi znanstveni časopis kojeg izdaje naš Fakultet, prvi broj objavljen je 2003. godine. Idejni začetnik Zbornika EFZG, ujedno i prvi glavni urednik Zbornika je pok. prof. dr. sc. Mato Grgić. Zbornik EFZG je otvorenog tipa bez pretplate i izlazi od 2009. godine dva puta godišnje u tiskanom i elektroničkom obliku. Odluku o objavljivanju članaka donosi međunarodno uredništvo nakon dvije anonimne recenzije. Od srpnja 2015. godine, uz radove na hrvatskom jeziku, Zbornik EFZG objavljuje i radove na engleskom jeziku. Časopis potiče objavljivanje radova mlađih znanstvenika i istraživača, samostalnih ili u koautorstvu, na domicilnom ili engleskom jeziku, koji na taj način ostvaruju uvjete za napredovanje u viša znanstvenonastavna zvanja, ali i stječu početna iskustva u znanstvenoistraživačkom radu. Prilikom objavljivanja posebno se vrednuju rukopisi s izraženim teorijskim i empirijskim doprinosom koji sadrže preporuke nositeljima ekonomske politike i široj stručnoj javnosti, a u svrhu snažnijeg povezivanja teorije i prakse ali i snažnijeg kritičkog promišljanja o aktualnim zbivanjima u ekonomiji. Specijalan fokus časopisa su zemlje Središnje i Istočne Europe no istraživanja koja se orijentiraju na druge regije također su dobrodošla, posebice ako su fokusirana na teorijska, aplikativna i empirijska saznanja vezana uz ekonomiju i poslovnu ekonomiju posttranzicijskih zemalja. Od autora se posebno očekuje doprinos u sljedećim područjima istraživanja: praćenje najnovijih dostignuća u području ekonomske znanosti i njihova primjenjivost u rješavanju razvojnih problema hrvatskog gospodarstva; istraživanje uloge visokoškolskog ekonomskog obrazovanja u gospodarskom razvoju, ekonomski položaj malih otvorenih zemalja u uvjetima integracijskih procesa u Europi i globalizacijskih procesa u svijetu, analiza faktora rasta i strukturnih promjena u hrvatskom gospodarstvu, osiguranje kontinuiranog uravnoteženog rasta hrvatskog gospodarstva, uklanjanje zapreka gospodarskom razvoju, podizanju kvalitete života građana i zaštiti okoliša, komparativna analiza razvoja susjednih zemalja i analiza komparativne konkurentnosti gospodarstva, usklađenost financijskog i realnog sektora gospodarstva, istraživanje i prognoziranje tržišne konjunkture, metode unapređenja poduzetništva, poslovne efikasnosti i konkurentnosti poduzeća, efikasnost tržišta i države i izgradnja primjerene institucionalne infrastrukture i dr. Zbornik Ekonomskog fakulteta u Zagrebu je citiran u sekciji New Journals časopisa Journal of Economic Literature (JEL) od rujna 2007. godine. Također, časopis je ocijenjen i uključen za listanje u AEA elektronskim indeksima, koji su uključeni u JEL na CD-u, e-JEL i EconLit, EBSCO, ProQuest ABI/Inform Complete, ProQuest Business Premium Collection, ProQuest East \& Central Europe Database i Social Science Premium Collection. Od 2017. godine putem sustava za provjeru izvornosti Turnitin radi se provjera izvornosti stručnih i znanstvenih radova pristiglih za objavljivanje u Zborniku EFZG. Od 2017. godine svakom pojedinom radu se dodjeljuje DOI broj što pridonosi većoj globalnoj vidljivosti radova i samog časopisa. Informacije o Zborniku EFZG možete pronaći na web mjestu Zbornika na stranici Ekonomskog fakulteta http://www.efzg. unizg.hr/default.aspx?id=6006 i na portalu znanstvenih časopisa Republike Hrvatske Hrčak http://hrcak.srce.hr/zbornik-efz. S obzirom da se ove godine obilježava stogodišnjica Ekonomskog fakulteta, nakon uvodnika o povijesti Zbornika EFZG objavljujemo tekst gosp. Željka Sirka vezano uz kratki pregled povijesti Ekonomskog fakulteta.

U Zagrebu, prosinca 2020.

Prof. dr. sc. Anita Pavković, glavna urednica 